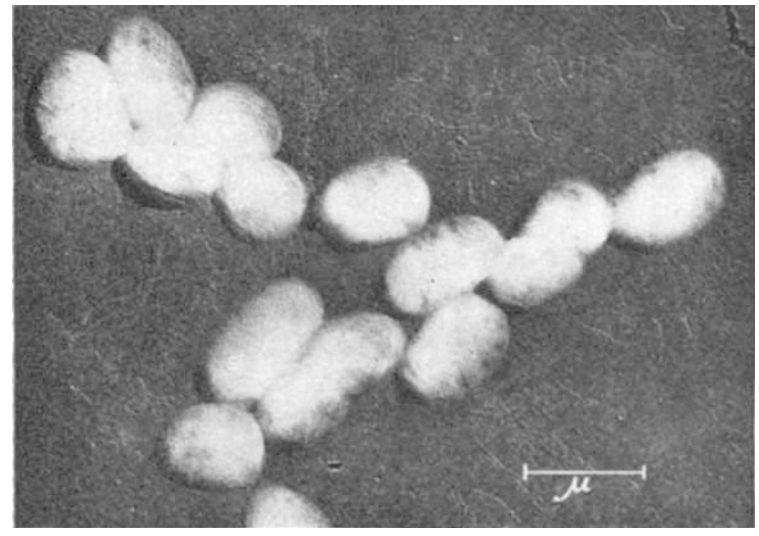

Fig. 1. Electron micrograph of the newly isolated coccus grown in a synthetic medium containing 'Tween $80^{\circ}$ ' as a sole source of carbon for $6 \mathrm{hr}$. I Shadowed with chromium. Flagella-like structure around the cell periphery were observed. The electron-transparent regions immediately inside the cell wall were observed only in the cells in the logarithmic growth phase; their nature and the mechanism of formation are now under investigation

of $0 \cdot 5-1 \cdot 2 \mu$ in diameter, occurring singly, in pairs or in clumps. It was non-motile, but flagella-like structures were observed by electron microscopy (Fig. 1). Growth occurred well on nutrient agar, blood agar and especially well on 'Tween'-agar' under aerobic conditions, developing smooth, flat and greyishwhite colonies. Sugar fermentation was very poor : glucose, arabinose, xylose and galactose gave slight acid formation only after long incubation (2-4 days). Simmons's citrate test was positive; urease was negative. Nitrates were not reduced to nitrites; catalase was positive; indole was not formed; gelatin was not liquefied within $2-3$ weeks.

In general, taxonomic characteristies of this organism resembles closely Neisseria catarrhatis (Frosch and

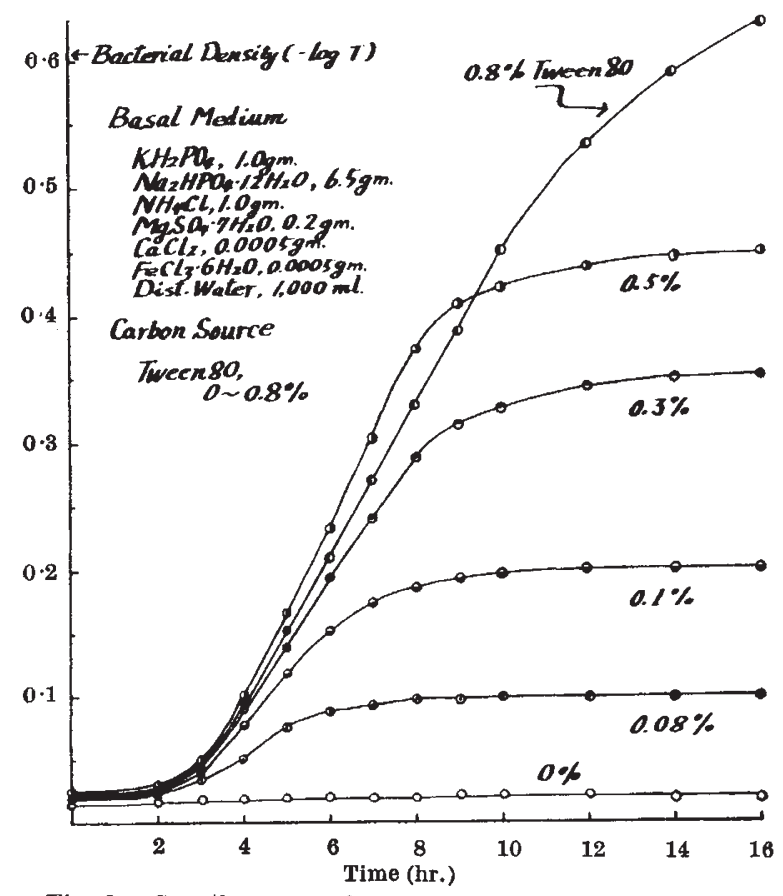

Fig. 2. Growth curves of a newly isolated coccus grown in synthetic media containing 'Tween $80^{\prime}$ as sole source of carbon. The concentration of 'Tween $80^{\prime}$ was varied from 0.08 to $0.8 \mathrm{per}$
cent. The culture was shaken at about 55 strokes per min. at $37^{\circ} \mathrm{C}$.
Kolle) Holland ${ }^{5}$, but it differs in its habitats and some of its sugar fermentations. So this organism belongs to the Micrococcaceae rather than to the Neisseriacese, but no description corresponding to this organism has been found in Bergey's system ${ }^{5}$. I believe it is a new strain of Micrococcaceae, and propose the name Micrococcus tweenis for it. (The details of the taxonomic description will be presented elsewhere.)

Fig. 2 shows the growth-curves of this organism grown in synthetic media' containing 'Tween $80^{\prime}$ as a sole source of carbon. The higher the concentration of 'Tween 80' used, the more abundent was the growth; and if no 'Tween 80' was added, no growth was observed.

'Tween 80 ' $(0.05-0.8$ per cent) stimulated the oxygen uptake of the cell suspension prepared from an 18-hr. culture grown on 'Tween'-agar medium. The oxygen uptake was also stimulated vigorously by such long-chain higher fatty acids and substances related to the tricarboxylic acid cycle such as oleate, stearate, palmitate, acetate, succinate, malate, fumalate, glutamate and aspartate, and to some extent by citrate and lactate.

Details of investigations with this organism will be reported elsewhere.

Department of Bacteriology,

Fukushima Medical College, Fukushima, Japan.

${ }^{1}$ Minami, K., Yamane, I., and Yasui, T., Fukushima J. Med. Sci. Japan, 1, 95 (1954). Yamane, I., Minami, K., and Yasui, T. C.R. Soc. Biol., Paris, 148, 769 (1954).

${ }^{2}$ Yamane, I., Hyodo, S., Honda, T., and Kadoya, K., Fukushima J. Med. Sci., Japan, 2, 35 (1955). Minami, K., and Yamane, I., Symposium on Enzyme Chem., Japan,
10,93 (1954).

- Edson, N. L., Bact. Rev., 15, 147 (1951). s Breed, R. S., Murray, E. G. D., and Hitchens, A. P. "Bergey's
Manual of Determinative Bacteriology", sixth edit. (Williams and Wanual of Determinative Bactering Co., Baltimore, 1948).

\section{Polyploidy in Bluebells}

IN my preliminary account ${ }^{1}$ on polyploidy in bluebells (Endymion nonscriptus (L.) Garcke, and $E$. hispanicus (Mill) Chouard), I mentioned that some of the huge forms in gardens which $I$ found to be triploids looked very much like the central one of Turrill's coloured figures ${ }^{2}$. Owing to the absence of any caption on Turrill's figures, I was led to take this huge central figure as the putative hybrid between the two species which Turrill mentions in his text. A few months after my publication, Turrill ${ }^{3}$ explained his figures and pointed out that the central figure was $E$. hispanicus; he also suggested that since I did not examine his own material cytologically the material which I examined and found to be triploid might be different from his in ploidy.

I therefore asked for some of his material of $E$. hispanicus, most of which on cytological examination I found to be triploid. Thus it seems there is little doubt but that the huge bluebell represented by the central figure of Turrill's coloured figures is the triploid of $E$. hispanicus and not the ordinary (diploid) form.

\section{Botany School,}

\section{J. YANNEY WHSON*}

Cambridge.

- Present address: University College of Ghana, Achimota.

1 Wilson, J. Y., Nature, 178, 195 (1956).

\& Turrill, W. B., Curtis's Bot. Mag., N.S., 176 (1952).

Turrill, W. B., Nature, 178, 706 (1956). 